\title{
Correction: Antenatal thoracoamniotic shunting in congenitalcystic adenomatoid malformation
}

The original version of this article contained a mistake. The measurements of the lesion are given in millimetres, whereas they should in fact be in centimetres. The updated text appears below:

Fetal MRI demonstrated a cyst measuring $6.7 \mathrm{~cm} \times 4.3 \mathrm{~cm}$, associated with mediastinal shift and affecting cardiac contractility. Scalp oedema and ascites noted at this time indicated evolving fetal hydrops.

At 28 weeks, thoracoamniotic shunt was inserted to drain the lesion. By 29 weeks, the cyst had decreased in size, now $5.1 \mathrm{~cm} \times 3.4 \mathrm{~cm}$. Cardiac function, oedema and ascites had all improved.

(c) BMJ Publishing Group Ltd (unless otherwise stated in the text of the article) 2018. All rights reserved. No commercial use is permitted unless otherwise expressly granted.

BMJ Case Rep 2018. doi:10.1136/bcr-2016-217940corr1

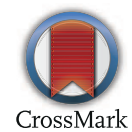

Copyright 2017 BMJ Publishing Group. All rights reserved. For permission to reuse any of this content visit http://group.bmj.com/group/rights-licensing/permissions.

BMJ Case Report Fellows may re-use this article for personal use and teaching without any further permission.

Become a Fellow of BMJ Case Reports today and you can:

- Submit as many cases as you like

- Enjoy fast sympathetic peer review and rapid publication of accepted articles

- Access all the published articles

- Re-use any of the published material for personal use and teaching without further permission

For information on Institutional Fellowships contact consortiasales@bmjgroup.com

Visit casereports.bmj.com for more articles like this and to become a Fellow 